の時排泄されたポルフィリンがコプロポルフィリンであ るととは，ルティジニー氷を展開溶媒とした Paper cohrmatograpfy で確恶し，定量はSchwartzらの方法 による抽出を行ない Beckmann 型分光光度計で比色定 量した。

家鬼は4 匹学用い，昇承 $0.5 \mathrm{mg} / \mathrm{kg}$ の皮下注射学隔 日に 5 回行ない，注射前，注射期間中，注射後の比较を

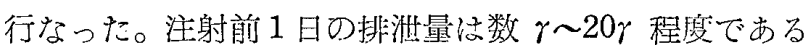

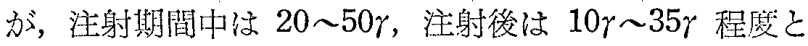
なった。てれらの結果から，水銀懪露時に尿中コプロポ

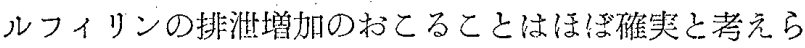
れる。

しかし水銀提取䥣の大きい場合，または非常に少ない 場合については，今後の検詂が必要であろう。

\section{0. 水銀中畵の解毒に関する研究}

大橋和夫，森 崇，大橋忠，西村正雄 上田善一（東京柬大・衛生）

水銀中毒の解毒剂として，徒来から種々なものが登げ られてきたが，BAL が登場して以来，他は全く影在ひ そめた感か深い。しかし BAL 筋洼以外に用いにくく 産業現場における尒防的治療郕としては適当でない。私 どもは天然に存在するDtihiol 化合物として，B群ビタ ミンに属するリポ酸(Thioctic acid)(以下 TA と略す) に着目し，水銀化合物との容器內絡合，マウス，ラッテ

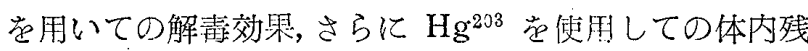
留率等を检討して，その解毒效果虏証明した。（石井： 産業医学 $1: 7.8 . P 162.1949 .11)$ しかし水銀接触者に TA 苍内服せしめると，尿中 $\mathrm{Hg}$ の増加しない例も多 数みられ，尿中 $\mathrm{Hg}$ 排泄と投与量との関係を追求する 必要を認めた。

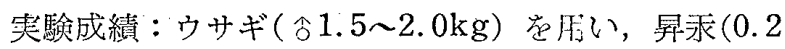

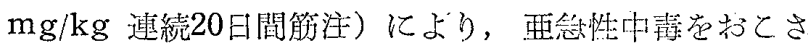
しめ，これに TA.DL-Dihydro-thioctic acid（以下 DTA と略宁), Thioct-amide, BAL 等を投与し, 24 封間尿中 $\mathrm{Hg}$ 排泄量を比較した。TA と DTA に劣い て客 $20 \mathrm{mg} / \mathrm{kg}$ 岩隔日に筋注したととろ, DTA の方が TA.より效果が大で市った。つぎに BAL，DTA を 0.2 そり当量 $/ \mathrm{kg}$ (BAL $24.8 \mathrm{mg}$, DTA $41.6 \mathrm{mg}$ )，辈続 3 日間筋注し，その $\mathrm{Hg}$ 排泄量を検討した結喿，BAL 㹥 DTA の約 2〜3 倍に達した。投与中止後，5日目 にいずれも前值虑下廻った。Thioct-amide は 4\% 搌 粉溶液に䀣罢し，第 1 日 $100 \mathrm{mg} ， 2$ 日目 $50 \mathrm{mg}$ ，以後 $10 \mathrm{mg}$ 学連日経口投系した結果，DTA より劣るが，
TA 占りはやや良好なる值を示した。また DTA 0.4 ミ リ当量 $/ \mathrm{kg}$ 岩グルクロン睃と併用したととろ，效果为認 められるものもあったが，全く效果若示さないものもあ った。

水銀解毒效果络然らずしも尿中排泟增加と注平行しな いであろう。難溶性化合物の生成渄泄が遅れ，また腸 管への排浛も可能である。したがって以上の成績から， 治療效果を比較するととはできない。

\section{1. 鉱山水銀中毒臨床知見補遺}

豊福 豊, 攻曽武决, 村中忠孝 (碞見济学织病院)

当院において，水銀中毒症として，入院治療点りけ， 識場復㴆した水銀鉱山従業貝 6 名の.万ち 1 年以内に再発 入院した 3 名についての䧗床知㫕定報告する。

症例はいずれも慢性型に属し，全身倦意感，頭痛，不 跟, 背部痛等の一般症状と, 㽷毒性震顫, 失調症状, 発 語障慧, 精神障害在是している。

Dithizon 法によって定量した退院時の1日氺中水銀

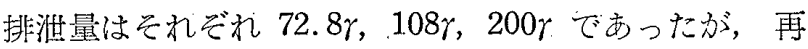
入院時時には $691 \gamma, 970 \gamma, 708 \gamma$ に増加している。入院 後の尿中水銀量の消長は，3 月月までは著明な減少を示 すが，4力月以後は減少度が減ずる。

脳脊髄液，垂液中の水銀量は Dithizon 法によっては 定量できなかった。

肝機能検查，筒機能検查は概ね正常值定示す。

自律神経機能検查では，交悘神経，副交感神経の緊張

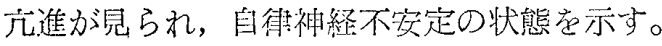

血液所見では好中性球の比較的減少とリンパ球の增多 內認められる。

箭電図では grouping voltage が灵られた。

現在も引引続経過観察中で，職場復帰に関して，尿 中水銀排浛量の最終目標をどの程度におくべきか検討中 である。

\section{2. マンガン中毒の臨床的研究}

弘瀬宏忠，鈴木幸夫，西山敬太郎 柴田 稕亳（德島大・衛生）

某 Mn 鉱山学務者について, 主として臨床的矿究苑行 なった。注目ずべ豆所見は基礎新湈代謝の艺焦で，16名 中14名がいずれも无進を示し，平均で+29.51\%。という 高い值であった。

白覚的，他覚的症状は征莱，当教室で報告したような 諸症状をさらに碓かめ得た。即ちこれら法四肢の震䫟, 